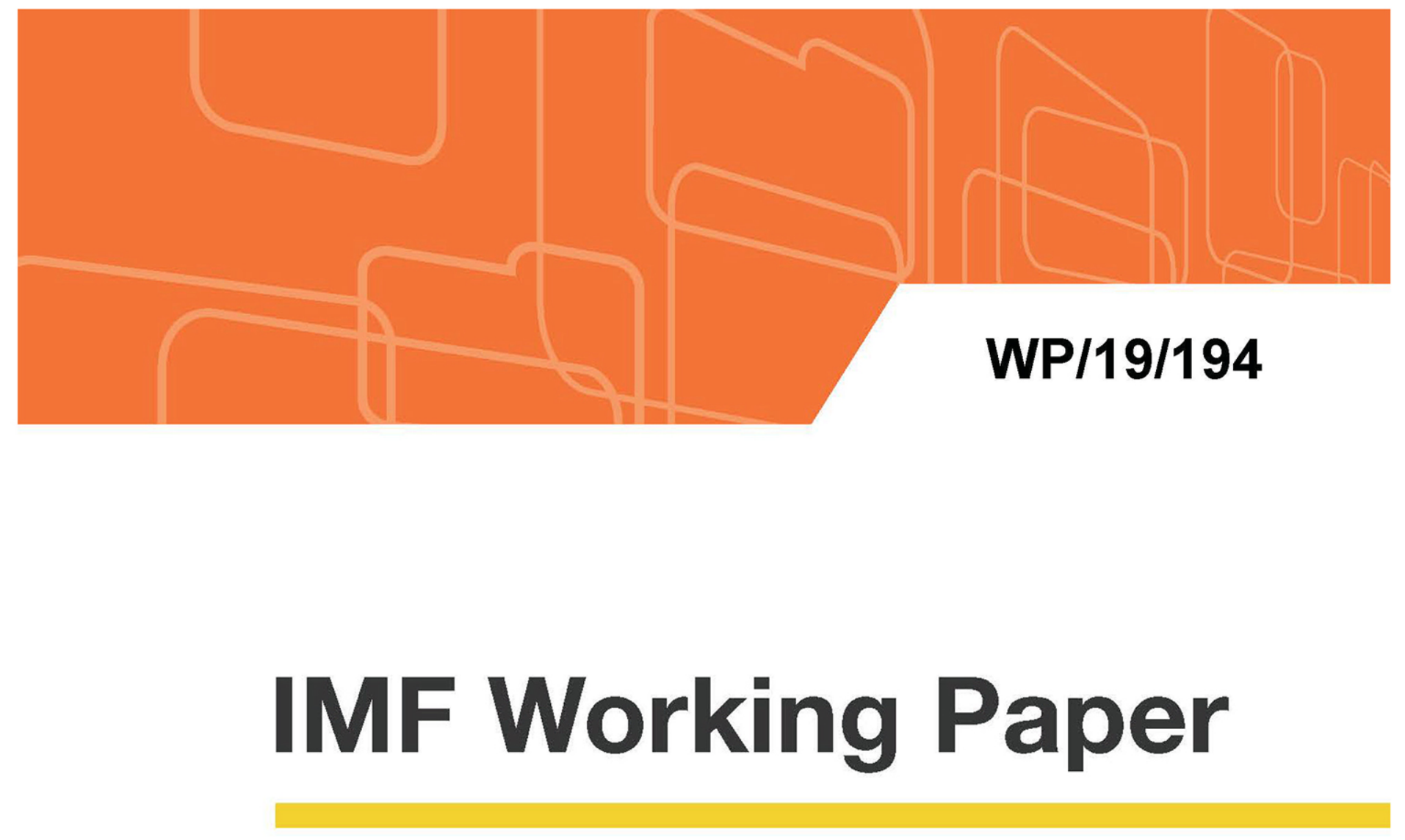

\title{
Financial Openness and Capital Inflows to Emerging Markets: In Search of Robust Evidence
}

by Diego A. Cerdeiro and Andras Komaromi

IMF Working Papers describe research in progress by the author(s) and are published to elicit comments and to encourage debate. The views expressed in IMF Working Papers are those of the author(s) and do not necessarily represent the views of the IMF, its Executive Board, or IMF management. 


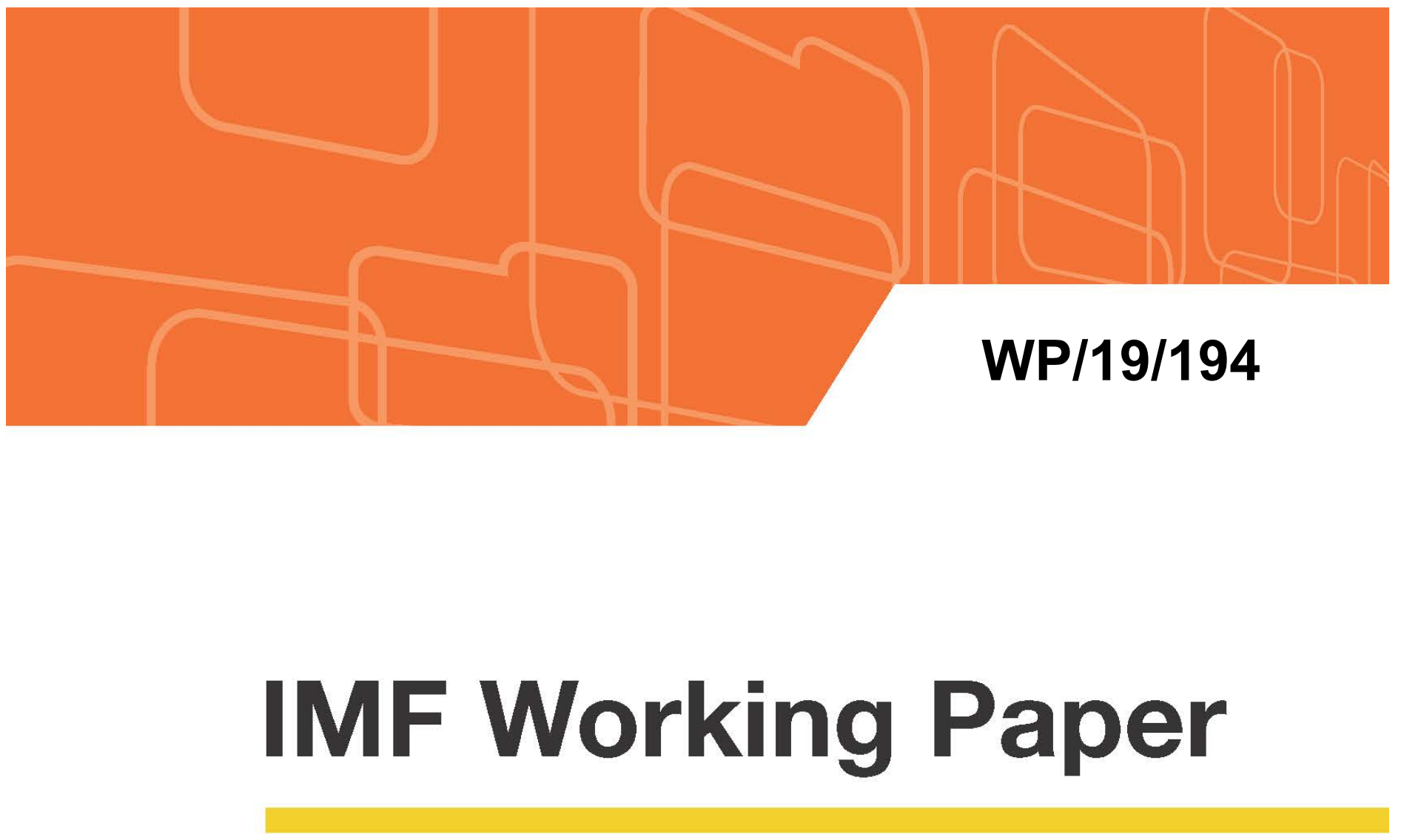

\section{Financial Openness and Capital Inflows to Emerging Markets: In Search of Robust Evidence}

by Diego A. Cerdeiro and Andras Komaromi

IMF Working Papers describe research in progress by the author(s) and are published to elicit comments and to encourage debate. The views expressed in IMF Working Papers are those of the author(s) and do not necessarily represent the views of the IMF, its Executive Board, or IMF management.

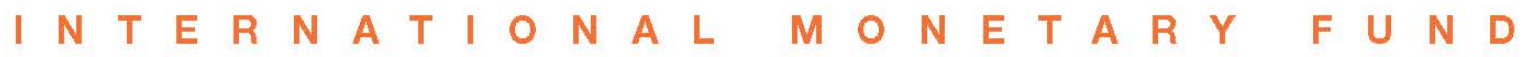




\title{
IMF Working Paper
}

Strategy, Policy and Review Department and Institute for Capacity Development

\section{Financial Openness and Capital Inflows to Emerging Markets: In Search of Robust Evidence}

\author{
Prepared by Diego A. Cerdeiro and Andras Komaromi* \\ Authorized for distribution by Martin Kaufman
}

September 2019

\begin{abstract}
IMF Working Papers describe research in progress by the author(s) and are published to elicit comments and to encourage debate. The views expressed in IMF Working Papers are those of the author(s) and do not necessarily represent the views of the IMF, its Executive Board, or IMF management.
\end{abstract}

\begin{abstract}
We reassess the connection between capital account openness and capital flows in an empirical framework that is grounded in theory and makes use of previously unexplored variation in the data. We demonstrate how our theory-consistent regressions may overcome some ubiquitous measurement problems in the literature by relying on interaction terms between financial openness and traditional push-pull factors. Within our proposed framework, we ask: what can be said robustly about the effect of capital account restrictions on capital flows? Our results warrant against overinterpreting the existing cross-country evidence as we find very few robust relationships between capital account restrictiveness and various types of capital inflows. Countries with a higher degree of financial openness are more susceptible to some, but by no means all, push and pull factors. Overall, the results are still consistent with a complex set of tradeoffs faced by policymakers, where the ability to shield the domestic economy from volatile capital flow cycles must be weighed against the sources of exogenous risks and potential long run growth effects.
\end{abstract}

JEL Classification Numbers: E58, F21, F32, G28.

Keywords: Capital flows, financial openness, capital flow management, capital controls.

Author's E-Mail Address: dcerdeiro@imf.org; akomaromi@imf.org

\footnotetext{
* We are very grateful to Martin Kaufman, Thomas McGregor and Erlend Nier for very helpful comments. All errors are ours.
} 


\section{Introduction}

Volatile capital flow cycles since the 2008 financial crisis have drawn renewed attention to policy measures aimed at constraining the free flow of capital between countries. Most studies that assess the effectiveness of these measures largely focus on the link between capital flows and the economy (such as the likelihood of crises), generally finding them to be effective in reducing macroeconomic and financial vulnerabilities. ${ }^{1}$ In comparison, evidence on whether capital flow management measures (CFMs) can directly affect the volume of flows is weaker. ${ }^{2}$ The search for evidence to this end using cross-country data, while appealing from an external validity standpoint, is fraught with problems: from the challenges involved in consistently summarizing financial account restrictiveness to controlling for unobserved country heterogeneity. In this paper, we reassess the connection between financial account restrictions and actual capital flows through an empirical framework that, relative to earlier work, is better grounded in theory and makes use of previously unexplored variation in the data in such a way that should help mitigate the empirical challenges. Within this framework, we ask: what can be robustly said about the effect of financial account restrictiveness on capital flows?

The cross-country empirical literature struggles with two interrelated problems. First, quantifying the restrictiveness of countries' capital flow regimes is notoriously difficult, which has led to a series of competing measures that may send conflicting signals. For example, we document that popular measures of de jure financial openness are very weakly correlated along the time dimension - the correlation can sometimes even be negative. This means that, depending on the particular measure used, a country's legal framework may seem to be evolving towards a more open or more closed financial account. Second, despite substantial cross-country differences in openness, capital account policies tend to be very persistent at

\footnotetext{
${ }^{1}$ IMF (2016) provides a brief overview of some recent contributions. See Gosh, Ostry and Qureshi (2018) for a book-length survey.

${ }^{2}$ For example, in their meta-analysis of the literature Magud, Reinhart and Rogoff (2018) conclude that capital controls on inflows may have altered the composition of flows and made monetary policy more independent, but they were ineffective at reducing the volume of net flows.
} 
the country level. Unfortunately, omitted variable concerns force researchers to rely on this limited time variation to identify the effect of controls on capital flows. This identification strategy, of course, exacerbates the aforementioned problem of diverging financial openness measures. Technically speaking, standard regression specifications include country fixed effects to control for unobserved factors, but these fixed effects soak up all the cross-sectional variation in openness, and make it naturally challenging to find consistent and significant effects using only changes in capital flow restrictions over time.

We argue that a richer and more theory-consistent empirical specification should help mitigate these challenges. Usually researchers assume an additive linear effect of CFMs on the level of capital flows in the standard push-pull framework. We show, in a simple intertemporal portfolio diversification model, that the degree of financial account openness interacts with other factors in determining capital flows. In other words, financial openness affects the sensitivity of capital flows to various push and pull factors identified in the literature. Thus, the constant-coefficient restriction is not theory-consistent.

Crucially, our new specification can exploit the cross-sectional variation in capital account openness, which has been largely ignored so far. Since the interaction terms are not washed out by the fixed effects, one could infer the effectiveness of CFMs by examining whether countries at different levels of financial openness have systematically different sensitivities to standard push and pull factors that drive capital flows. An important additional benefit of this approach is that exploiting the cross-sectional dimension of the data can mitigate the uncertainty from alternative measures. This is because available indicators of financial openness are very strongly correlated in the cross section of countries. That is, they may not agree whether a country is inching toward more or less financial openness, but they broadly agree on the ranking of countries according to their average degree of restrictiveness. Consequently, key within our exercise is examining the robustness of our results using several measures of financial openness.

Analyzing capital account policies and capital flows to EMs through our proposed frame- 
work, we do not find overarching and robust evidence to support the efficacy of CFMs to manage the volume of inflows. Countries with a higher degree of financial openness are more susceptible to changes in some, but by no means all, push and pull factors. We find relatively robust evidence that portfolio equity inflows in more open countries are more exposed to changes in U.S. interest rates. Compared to equity inflows, in the case of debt inflows more open countries appear more susceptible to changes in expected domestic returns and less responsive to changes in U.S. rates. We find no robust evidence that higher financial openness leaves countries more exposed to swings in global risk aversion or to changes in the global growth outlook, as the results in those cases differ depending on how financial openness is measured and precision in estimates tends to be low. Looking beyond portfolio flows, a significant downside of lower financial openness lies in the weaker response of FDI inflows to domestic growth. In fact, no finding is as robust and significant as the one showing that, when expected domestic growth is higher, FDI inflows expand significantly more in more open countries. Overall, the few relatively robust results point to tradeoffs faced by policymakers, where the ability to shield the domestic economy from volatile capital flow cycles must be weighed against the sources of exogenous risks and potential long run growth effects.

Related literature. We build on the literature that constructs indicators of de jure financial openness or capital account restrictiveness (e.g. Chinn and Ito, 2008; Quinn, 1992; Schindler, 2009; Fernández et al., 2016; Jahan and Wang, 2016). Quinn, Schindler and Toyoda (2011) compare many of these indicators, and show that the choice of measure matters greatly for the estimated relationship between growth and financial openness. We also analyze the similarities and differences of these indices across countries, but with the aim of focusing our empirical work on features of the data where there is the most agreement. In particular, our comparison of de jure openness measures motivates us to derive a specification that uses the cross-country variation in capital account openness. 
We follow much of the empirical literature that uses the 'push-pull' framework to analyze capital flows to emerging markets. The distinction between country-specific 'pull' and external 'push' factors was introduced by Calvo, Leiderman and Reinhart (1993) and Fernandez-Arias (1996). Koepke (2015) provides an extensive survey of the ensuing vast empirical literature. Interestingly, the 'push-pull' framework for the drivers of capital flows emerged from the empirical literature without explicit reference to formal economic theory. In this paper, we provide a simple small open economy model with risk averse investors to motivate the push-pull regressions that are omnipresent in the empirical literature. Although intertemporal optimization and risk-return considerations yield a familiar-looking linearized equation, the model implies interesting interactions between capital controls and push-pull factors that are absent in standard specifications.

Finally, our work is closely related to the literature on the effects of capital controls on various economic outcomes, such as the volume or composition of inflows, financial stability, or the likelihood of crises (see chapter 9.4 in Gosh, Ostry and Qureshi (2018) for a survey). Our work complements this literature. More specifically, because we argue that the correct empirical strategy involves a specification that interacts push and pull factors with the degree of financial openness, our results can provide answers to a different set of questions. Do financial account restrictions have a significant effect on how certain types of inflows react to increases in the U.S. interest rate? Do they affect how sensitive inflows are to changes in the growth outlook of the country? Answers to these questions can contribute to debates about the ability of countries to insulate themselves from the financial cycle (Rey, 2015), and the costs of any measures used to that end (Forbes, 2005). ${ }^{3}$

\footnotetext{
${ }^{3}$ Our conceptual framework also implies that the effect of capital controls depends on the level of push and pull factors. This is just the dual to the interpretation we focus on in this paper.
} 


\section{A conceptual framework}

This section provides a simple model that will ground and guide the empirical strategy. The main goal is to derive from first principles a linear estimation equation that resembles the standard push-pull regressions found in the empirical literature. Consider the following two-period small open economy.

The small open economy. The economy is populated by a continuum of households with logarithmic preferences over consumption. The period-1 endowment $y_{1}>0$ is deterministic, but output in period 2 is uncertain:

$$
\ln y_{2}=\mu+\varepsilon
$$

with $\varepsilon \sim N\left(0, \sigma_{\varepsilon}^{2}\right)$. For easier interpretation, we will assume $\mu=\ln y_{1}+g-0.5 \sigma_{\varepsilon}^{2}$, which ensures that the expected growth rate of the economy is $g$. The household can trade shares in period-2 output (i.e. a GDP-linked bond) with risk averse international investors whose pricing kernel will be described below. Let $v_{1}$ denote the period-1 value of period-2 output and $\alpha$ the fractional shares sold to international investors in period 1. Capital controls are captured by a proportional tax $\tau \in[0,1]$ on foreign capital inflows that the government rebates to households as a lump sum transfer. We can interpret a country with a high $\tau$ as having a relatively closed financial account. ${ }^{4}$ The representative household maximizes

$$
\ln c_{1}+\mathbf{E}\left[\ln c_{2}\right]
$$

\footnotetext{
${ }^{4}$ Capturing capital controls this way in small open economy models is standard in the literature. See, for example, Jeanne and Korinek (2010) and Korinek (2018).
} 
over $\alpha$ subject to the budget constraints

$$
\begin{aligned}
& c_{1}=y_{1}+(1-\tau) \alpha v_{1}+t \\
& c_{2}=y_{2}(1-\alpha),
\end{aligned}
$$

where $t$ is the lump sum transfer so that $t=\tau \alpha v_{1} \cdot{ }^{5}$

The first order condition with respect to $\alpha$ can be written as

$$
\frac{(1-\tau) v_{1}}{c_{1}}=\mathbf{E}\left[\frac{y_{2}}{c_{2}}\right] .
$$

Using the household's budget constraints and $t=\tau \alpha v_{1}$, this yields

$$
\frac{(1-\tau) v_{1}}{y_{1}+\alpha v_{1}}=\frac{1}{1-\alpha}
$$

For a given share price $v_{1}$, this expression defines the economy's supply of shares, which in turn allows us to solve for all endogenous variables. Since our empirical analysis focuses on capital flows, let us re-arrange the above expression and define net capital inflows as a share of GDP:

$$
F \equiv \frac{\alpha v_{1}}{y_{1}}=\frac{1-\tau}{2-\tau} \frac{v_{1}}{y_{1}}-\frac{1}{2-\tau}
$$

International investors. To introduce risk aversion in international capital markets, we borrow from the literature on sovereign default (Arellano and Ramanarayanan, 2012) and assume that foreign investors price the GDP-linked bond using the following stochastic discount factor:

$$
m=e^{-r-\left(\lambda \varepsilon+0.5 \lambda^{2} \sigma_{\varepsilon}^{2}\right)}, \quad \text { with } \quad \lambda \geq 0 .
$$

\footnotetext{
${ }^{5} \mathrm{We}$ assume no discounting. All results are qualitatively identical if period-2 utility is discounted at a rate $\beta<1$. Since this is inessential and only complicates the expressions, we assume no discounting.
} 
where $r$ is the risk-free interest rate, and $\lambda$ determines the size of the risk premium. As explained in Bianchi, Hatchondo and Martinez (2018), this formulation results in a positive risk premium because the payoff from the GDP-linked bond is more valuable to lenders when the economy experiences a negative shock (low $\varepsilon$ ). A higher value of $\lambda$ can be seen as capturing the combined effect of two factors: (i) the intrinsic risk aversion of lenders and (ii) how correlated the small open economy is with the lenders' income process, or alternatively, the degree of diversification of foreign lenders.

Equilibrium capital flows. Using the distributional assumptions about $y_{2}$, the price of the GDP-linked bond must satisfy

$$
\begin{aligned}
\frac{v_{1}}{y_{1}} & =\mathbf{E}\left[m \frac{y_{2}}{y_{1}}\right]=\mathbf{E}\left[e^{-r-\left(\lambda \varepsilon+0.5 \lambda^{2} \sigma_{\varepsilon}^{2}\right)} e^{\mu+\varepsilon}\right] \\
& =\frac{e^{g}}{e^{r+\lambda \sigma_{\varepsilon}^{2}}} .
\end{aligned}
$$

The term $\lambda \sigma_{\varepsilon}^{2}$ measures the risk premium that risk-averse foreign lenders apply to the country's uncertain future income. Plugging this expression into (1), we obtain the solution for capital inflows as a share of GDP,

$$
F=\frac{1-\tau}{2-\tau} \frac{e^{g}}{e^{r+\lambda \sigma_{\varepsilon}^{2}}}-\frac{1}{2-\tau}
$$

For comparison with the regression specifications in the empirical literature, it is useful to take a first order approximation of this expression around $(\bar{r}, \bar{g}, \bar{\lambda})=(0,0,0) .{ }^{6}$ This yields:

$$
F \approx \underbrace{-\frac{\tau}{2-\tau}}_{\text {(i) }}+\underbrace{\frac{1-\tau}{2-\tau}}_{(\text {ii) }} g-\underbrace{\frac{1-\tau}{2-\tau}}_{(\text {iii) }} r-\underbrace{\frac{1-\tau}{2-\tau} \sigma_{\varepsilon}^{2}}_{(\text {iv) }} \lambda .
$$

This expression is intuitive in light of the empirical push-pull literature about the drivers

\footnotetext{
${ }^{6}$ This particular point of approximation is chosen to simplify the algebra. The main conclusion of the analysis does not depend on it.
} 
of capital inflows to emerging markets: (i) more restrictions on capital inflows (a higher $\tau$ ) reduce the amount of those inflows; (ii) higher domestic growth is associated with larger capital inflows; (iii) higher interest rates on international capital markets lowers capital inflows; and finally (iv) higher risk aversion (or stronger international co-movement of asset returns) leads to a drop in EM inflows.

Notice, however, an important additional effect of capital controls: higher $\tau$ also reduces the coefficients on growth, the foreign interest rate and risk aversion. Thus, the sensitivity of capital inflows to domestic pull and external push factors also depends on the financial openness of the country. This observation is at odds with the constant coefficient panel regressions in the literature that pool together many countries with vastly different levels of financial account openness.

\section{Empirical approach and data}

Guided by the conceptual framework laid out in Section 2, we estimate the following specification:

$$
F_{i, t}=\alpha F O_{i, t}+\left(\beta_{0}+\beta_{1} F O_{i, t}\right) \mathbf{p u l l}_{i, t-1}+\left(\gamma_{0}+\gamma_{1} F O_{i, t}\right) \mathbf{p u s h}_{t}+\delta \mathbf{x}_{i, t-1}+v_{i}+\varepsilon_{i, t}
$$

where $F$ denotes a type of non-official capital inflows measured as percent of GDP, $F O$ a

measure of financial openness, push a vector of push factors, pull a vector of pull factors, $\mathbf{x}$ a series of (non-interacted) controls, $v$ a country fixed effect, $\varepsilon$ is the error term, and the sub-indexes $i$ and $t$ correspond to country and time, respectively. Push factors include a U.S. short-term interest rate, expected U.S. real GDP growth, and a measure of global risk aversion. The pull factors include projected domestic output growth and the domestic interest rate corrected for expected exchange rate movements. We control in $\mathbf{x}$ for countries' 
institutional quality. ${ }^{7}$ We conduct the empirical analysis with monthly and quarterly capital flows. To mitigate potential endogeneity issues, all domestic variables are included with a lag. 8

Our focus is on capital inflows, defined as net acquisition of domestic assets by nonresidents. The capital inflow data source used depends on the type of flows. Quarterly FDI inflow data come from the Financial Flows Analytics (FFA) database. For non-FDI flows, we argue that quarterly data are not adequate for our purposes, as investors likely revise their portfolios at a higher frequency in response to changes in global and domestic conditions. While, to the best of our knowledge, no higher frequency data exist for 'Other inflows', monthly data on portfolio debt and portfolio equity inflows are available from the Institute of International Finance (IIF). ${ }^{9}$ The dataset includes 17 (16) mostly emerging-market (EM) countries for the case of portofolio debt (equity). ${ }^{10}$ All panels are unbalanced; the coverage for some countries goes back to January 2000, whereas for others the series start in January 2014.

Capital flows are expressed in annualized ratio to GDP measured in U.S. dollars. Global risk aversion is measured by the logarithm of the Chicago Board Options Exchange Volatility Index (VIX). Data on the VIX index and U.S. effective Fed Funds rate are retrieved from Haver Analytics. ${ }^{11}$ Domestic interest rate data are from the IFS database and Haver. The

\footnotetext{
${ }^{7}$ In unreported results, we also control for countries' GDP per capita and stock of external debt, without affecting the conclusions presented below. All non-reported robustness checks mentioned throughout the paper are available from the authors upon request.

${ }^{8} \mathrm{~A}$ one-month lag in the case of monthly series, and a 12-month lag in the case of controls and financial openness indices which are available at annual frequency.

${ }^{9}$ Section A.1 of the Appendix shows how IIF data correlate with balance of payments data, and also discusses the adequacy of another monthly dataset commonly referred to by capital flows analysts (EPFR).

${ }^{10}$ Porfolio debt data are available for Brazil, Bulgaria, Chile, China, Czech Republic, Hungary, India, Indonesia, Korea, Malaysia, Mexico, Philippines, Poland, South Africa, Thailand, Turkey and Ukraine. Portfolio equity data are available for all those countries except Malaysia. Our FDI regressions based on quarterly data include any other countries with at least eight quarters of data for all variables, thus also including Argentina, Bolivia, Colombia, Costa Rica, Dominican Republic, Ecuador, Egypt, Guatemala, Israel, Sri Lanka, Nicaragua, Peru, Paraguay, Saudi Arabia and Uruguay.

${ }^{11}$ We also explored the sensitivity of our results to using the Wu-Xia shadow Fed funds rate, which accounts for the effects of unconventional monetary policy at the zero lower bound (Wu and Xia, 2016), and replacing the VIX with the U.S. corporate BBB spread. Our findings are robust to these modifications.
} 
domestic returns pull factor included in the regression is equal to the domestic rate minus the expected exchange rate depreciation. Data on expected U.S. and domestic growth, and on expected exchange rate depreciation are based on the means reported by Consensus Forecast. ${ }^{12}$ Consensus Forecast surveys are based on target periods that only change once a year. For example, from January to December 2010 the survey provides a forecast for annual GDP growth in 2010 and 2011, and then in January 2011 the targets are shifted by one year. To get a stable forecasting horizon, we rely on weighted averages of current-year and next-year mean forecasts. Specifically, let $m$ denote the month $(m=1, \ldots, 12)$ and $f_{c}(m)$ and $f_{n}(m)$ denote current and next-year mean forecasts. The variables we use are defined as $g(m) \equiv \frac{12-m}{12} f_{c}(m)+\frac{m}{12} f_{n}(m)$. Lastly, institutional quality is measured via a simple average of all twelve subcategories included in the International Country Risk Guide (ICRG) index.

On measures of financial openness. The ideal measure of financial openness would be inversely related to the extent countries' legal systems restrict capital flows, accounting not only for differences in laws and regulations, but also in their enforcement. However, indexes of financial openness commonly known as de facto measures typically measure openness based on outcomes, as for example in the pioneering work of Lane and Milesi-Ferretti $(1999,2007)$ on countries' external balance sheets. This type of measure is not well suited for the objective of this paper. Our interest is in whether countries' actionable capital flow management policies affect actual capital flows, while outcome measures likely depend on a host of other policy and non-policy factors. Most importantly, such outcomes are partly explained, from a purely accounting point of view, by our left-hand-side variables of interest (different types of capital flows). We therefore focus exclusively on so-called de jure measures of financial openness that capture codified laws and regulations on financial account transactions.

\footnotetext{
${ }^{12}$ Four countries in our samples do not have Consensus Forecast data on expected exchange rate 12 months ahead. For these four countries (Bulgaria, Hungary, Czech Rep, and Poland), we have used used expected inflation instead of expected depreciation to calculate expected domestic returns.
} 
All existing de jure measures are based on the information compiled in the IMF's Annual Report on Exchange Arrangements and Exchange Restrictions (AREAER). The AREAER's questionnaire (available since the 1967 edition of the report) includes a summary table for binary (yes/no) answers, and an open-response part where relevant policies can be further explained in text form. The four alternative indexes we use differ in the extent to which the information content of the AREAER is exploited: ${ }^{13}$

Chinn-Ito index (Chinn and Ito, 2008). The Chinn-Ito index offers a long time series and wide country coverage. To achieve this, the index focuses on just four categories of balance of payment restrictions that are more or less consistently present going back to 1970, and entirely ignores possible intensity-related information present in the database's text. ${ }^{14}$

Quinn index (Quinn, 1992; Quinn and Toyoda, 2008). The Quinn index exploits the text of the AREAER to also judge the intensity of restrictions. Because the index also goes back before 1996, and pre-1996 AREAER editions do not provide information by asset class, it only offers slightly more disaggregation than the Chinn-Ito index by offering a breakdown into resident and nonresident restrictions. Since in this paper we focus on nonresident flows, we use Quinn's index measuring openness to nonresident flows.

Fernandez-Klein-Rebucci-Schindler-Uribe index (Schindler, 2009; Fernández et al., 2016). The FKRSU index covers a relatively shorter time period (1995 onwards), but it is based on a careful and systematic reading of the AREAER's text to code the presence of capital account restrictions for 12 distinct asset classes. The index also distinguishes restrictions on transactions by residents and nonresidents in the local market and abroad.

\footnotetext{
${ }^{13}$ A detailed description of the different financial openness indexes and their differences is beyond the scope of this paper. See Quinn, Schindler and Toyoda (2011) for a thorough discussion.

${ }^{14} \mathrm{~A}$ common, yet in our view misplaced critique of the Chinn-Ito index is that some of these categories are not capital and financial account restrictions. Insofar as the BOP follows double-entry conventions, many current account restrictions are also financial account restrictions (e.g. surrender requirements of export proceeds are potentially also a restriction on the net acquisition of foreign assets).
} 
Wang-Jahan index (Jahan and Wang, 2016). The Wang-Jahan index is similar to the FKRSU index. However, since it was developed with the aim of assessing openness in lower-income countries and thus offers a wider country coverage, it makes less use of the AREAER's text. ${ }^{15}$ This corresponds to the fact that for many low-income countries, simply no narrative is available. The original dataset developed by Jahan and Wang (2016) has data through 2013; data updated through 2015 are from Horn and Narita (forthcoming).

It is worth noting that two of the financial openness indexes used (FKRSU and WangJahan) offer measures of restrictiveness for different asset classes. This information can, in principle, be combined to try to match different types of restrictions to different types of capital inflows in the balance of payments. We do not present results adopting this approach for two reasons. First, assuming positive correlation between restrictiveness across asset classes, using average restrictiveness makes our results less likely to be affected by measurement error. More importantly, foreign investors that aim to invest in a particular asset class are likely to be mindful of any restrictions on other, related transactions. ${ }^{16}$

\subsection{Three stylized facts about financial openness indices}

This subsection documents three stylized facts about existing financial openness indices. The goal is to demonstrate how our sensitivity-based approach may overcome some of the difficulties in the empirical literature that tries to identify the effects of financial openness on capital flows.

Fact 1. Large dispersion across countries, little variation over time. Figure 1 shows, for the four different financial openness indices considered, the evolution of the median and

\footnotetext{
${ }^{15}$ A similar approach to develop a financial openness index is taken in a recent paper by Giordani et al. (2017).

${ }^{16}$ This would be the case if transactions involving other asset classes are necessary to carry out certain investments or liquidate positions. In their analysis of bank inflows, for example, Ghosh, Qureshi and Sugawara (2014) argue that "[w] hile loans (targeted directly by financial credit controls) tend to be the dominant component of cross-border bank flows, restrictions on direct investment flows, by limiting the establishment of branches/subsidiaries abroad, could indirectly affect loans by restricting intrabank transactions."
} 
interquartile range. Since the literature has usually focused on emerging market countries, we exclude advanced economies in constructing Figure 1, though the following features hold more generally. It is apparent from these charts that, in any given year, cross-sectional dispersion of openness among emerging market countries is very large. In fact, this crosssectional dispersion contributes most of the total variation in openness in the panel data of countries. Country dummies explain more than $80 \%$ of the total variation in openness in the data for any index. ${ }^{17}$ This variation must be left untapped in empirical estimates that rightly include country fixed effects to address unobserved heterogeneity but assume a linearly separable role of capital account restrictions.

Fact 2. Different measures often yield contradicting trends in financial account policies. The problem of openness varying relatively little over time is compounded by the fact that it is common for different measures of openness to disagree on the evolution of a country's policies. In Figure 2 we calculate the country-level pairwise correlations between different openness measures over time, and then plot the median, interquartile range, minimum and maximum correlations across countries. Even for the Wang-Jahan and FKRSU indices, which tend to agree more on changes in openness, for one-quarter of emerging markets the correlation is below 0.5. In all other cases, for more than a quarter of the countries in the sample the correlation is negative.

Fact 3. Different measures tend to rank countries' de jure openness consistently. Unlike the direction of change in financial account policies, the relative position of countries is quite similar regardless of the chosen measure. Figure 3 shows the cross-sectional correlations between the four openness indicators for selected years. Notably, the correlation coefficients are in the 0.75-0.95 range for all years and all indicator pairs. Thus, different methodologies to summarize legal restrictions on capital flows yield broadly consistent results when

\footnotetext{
${ }^{17}$ The range in our dataset is from $82.3 \%$ (Chinn-Ito) to $86.3 \%$ (Wang-Jahan). The remarkable persistence of capital account policies is also highlighted by Eichengreen and Rose (2014) who show that "controls on the international flow of financial capital are highly durable, often remaining in place for decades.",
} 
Figure 1: Different financial openness measures for emerging markets and developing countries: in the cross section and over time
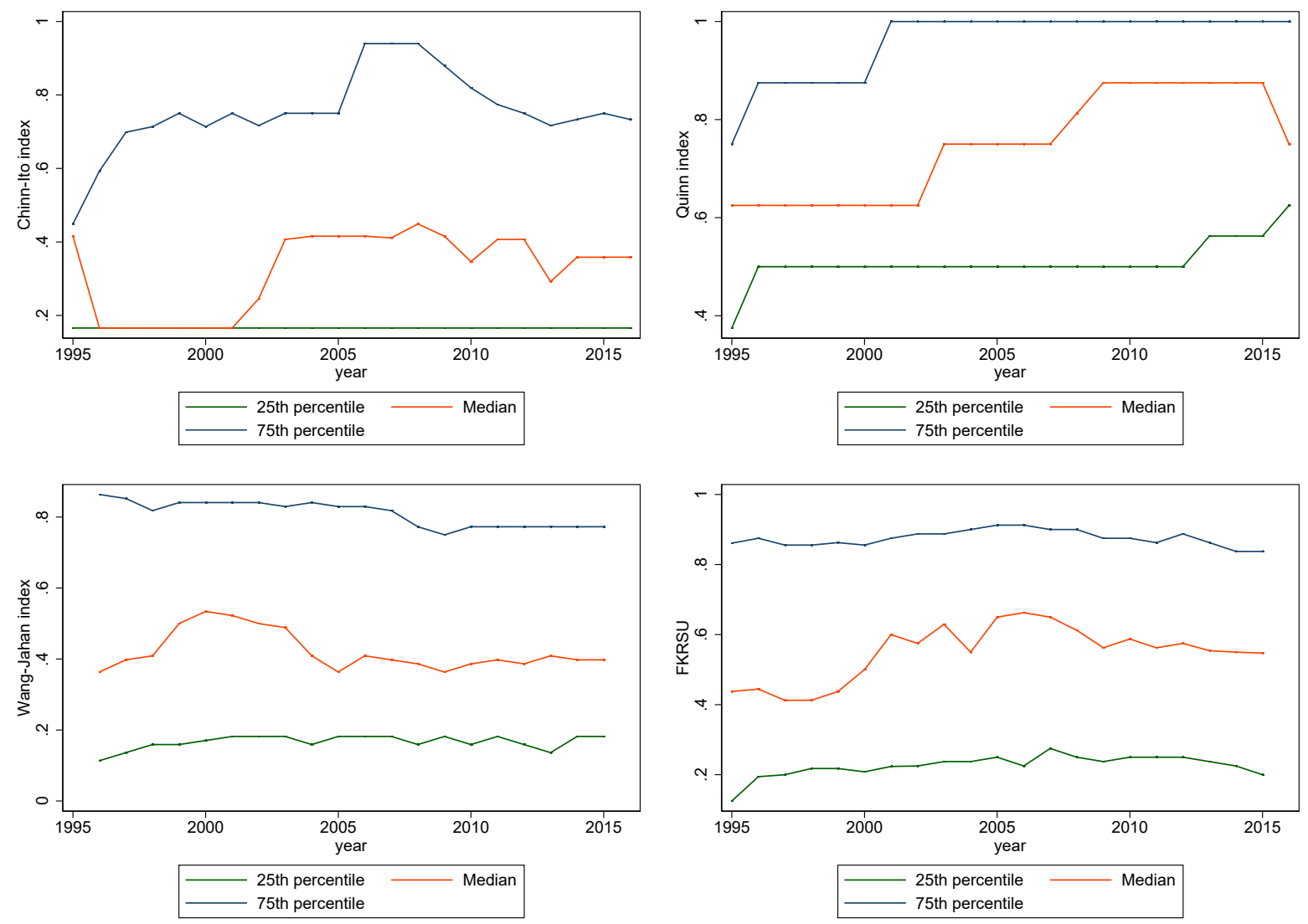

Notes: Each panel shows, for a given financial openness index, the 25th, 50th and 75th percentiles of openness levels for emerging market and developing countries. Clockwise from top left, these measures are: Chinn-Ito, Quinn, FKRSU, and Wang-Jahan. 
Figure 2: Pairwise time-series correlations of different financial openness indices

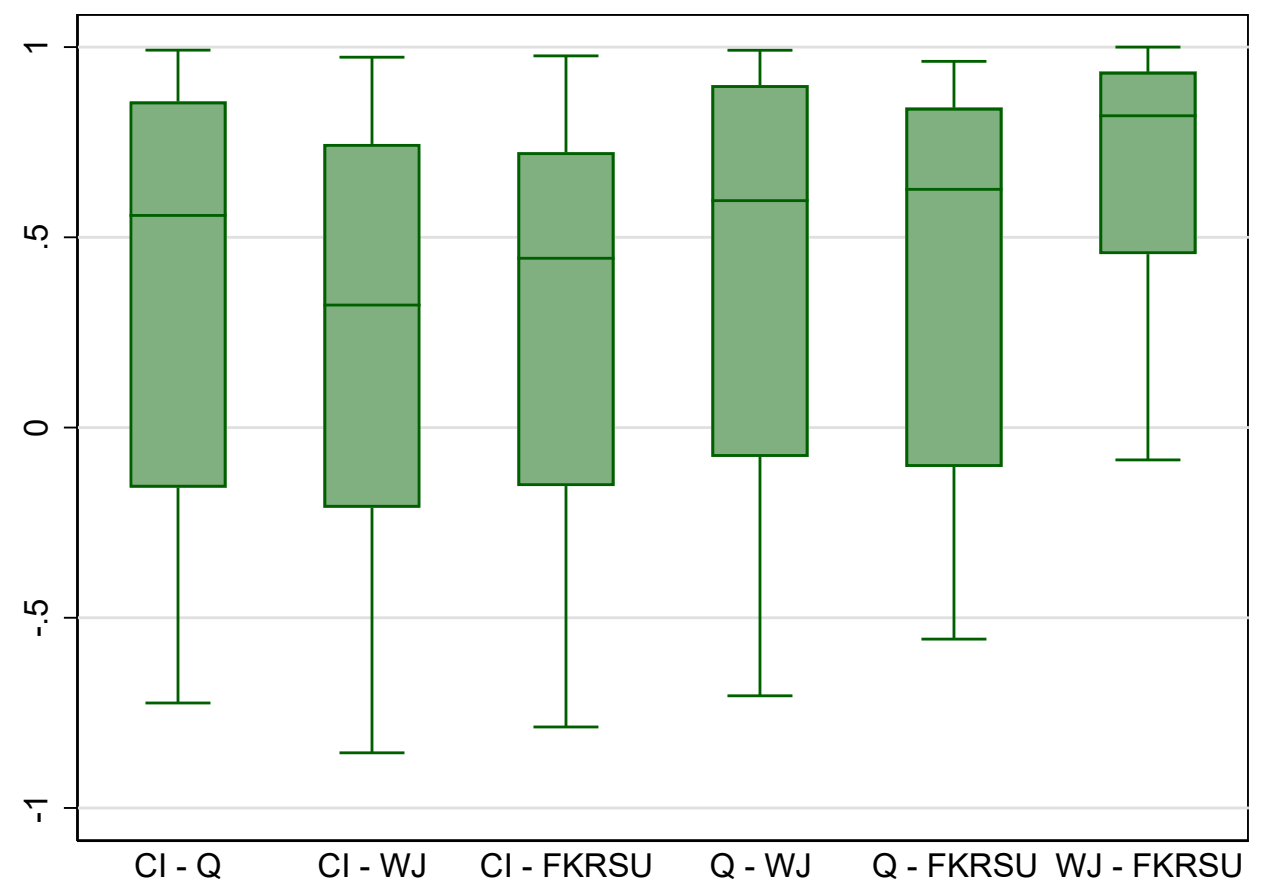

Notes: Each box shows the country-level, time-series correlation between two financial openness measures. The central line in each box corresponds to the median, and the box edges correspond to 25th and 75th percentiles. The top and bottom horizontal lines depict the maximum and minimum correlations. CI: Chinn-Ito, Q: Quinn, WJ: Wang-Jahan. 
Figure 3: Pairwise cross-sectional correlations of different financial openness indices

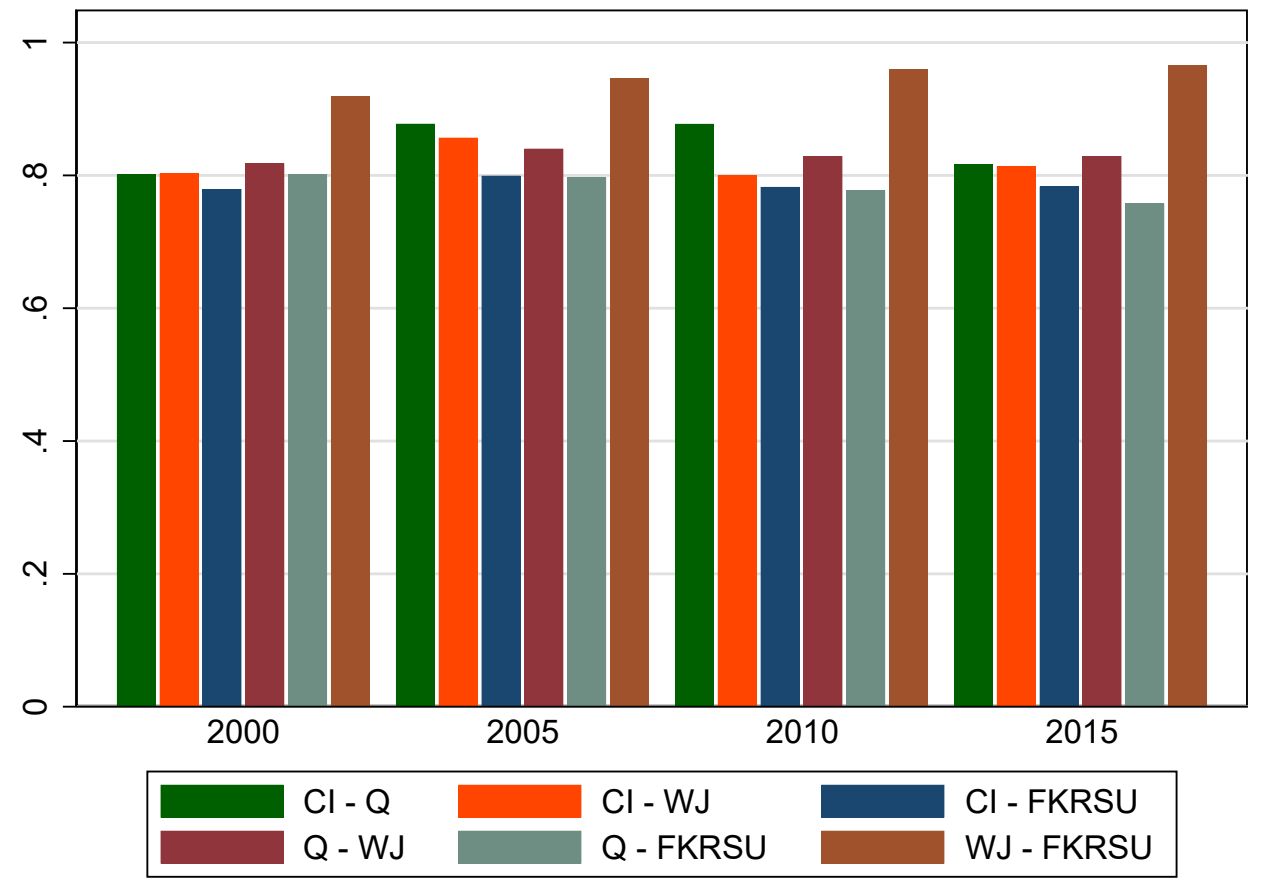

Notes: Each bar shows for a given year the cross-country correlation between two financial openness measures. CI: Chinn-Ito, Q: Quinn, WJ: Wang-Jahan.

comparing countries to each other.

These three facts imply that any robust cross-country empirical result linking de jure financial openness to the volume of capital flows should make use of the cross-sectional dimension of the data: this is where most of the observed variation comes from and this is where there is reasonable agreement between different measures. Our specification in (3) satisfies this requirement.

\section{Results}

Tables 1-3 in Appendix A.2 show the fixed-effect estimates of our push-pull regressions for portfolio equity, portfolio debt and FDI inflows, respectively. The within R-squared reported in the tables is in line with the levels typically found in the literature, and the institutional 
control, across all financial openness measures, has the expected sign: higher institutional quality is associated with larger inflows.

Recall that in our theory-consistent empirical framework the focus is on the differential impact of traditional push-pull factors at different levels of financial openness. Interpreting the estimated effects of push and pull factors directly from Tables 1-3 is complicated given the presence of interaction terms. To provide a visual aid, Figures 4-6 show for each type of inflow the estimated effects for countries at the 25th (blue dot) and 75th (red diamond) percentiles of the financial-openness distribution.

Figure 4 presents the results for portfolio equity inflows. Overall across emerging market countries, all results tend to have the expected sign across financial openness measures: equity inflows tend to increase the higher the expected domestic returns and the higher the expected growth, and tend to be lower the higher the U.S. interest rate, the higher the expected U.S. growth, and the larger the volatility. In terms of financial openness shaping these sensitivities, there is very strong evidence that more open countries are more susceptible to changes in U.S. interest rates. A one-percentage-point higher Fed Funds rate is associated with almost no change in equity inflows for a country on the 25th percentile of openness, and - depending on the measure of openness used - a decline in inflows of between 0.1 and 0.3 percent of GDP for a country on the 75 th percentile of financial openness.

There is relatively weaker evidence that more open countries tend to attract more equity inflows when domestic growth and expected domestic returns are higher. When expected domestic growth is one-percentage-point higher, a country on the 75 th percentile of openness may attract about 0.1 percent-of-GDP higher equity inflows than a country on the 25th percentile of openness. While the interaction term is generally not significant at standard confidence levels, the point estimates are broadly consistent across three different financial openness measures. The evidence on the effect of expected domestic returns is also mixed, with two measures indicating a statistically-significant effect (of between 0.03 and 0.08 equity inflows in percent of GDP) of a one-percentage-point higher expected domestic return for the 
75th-percentile country, while the remaining two measures showing virtually no differential effect.

Lastly, our assessment of the results presented in Figure 4 is that there seems to be no robust evidence that more open countries are more susceptible to portfolio equity outflows as a result of higher volatility or stronger U.S. growth. The results tend to differ across measures of financial openness and the estimated interaction terms are by and large not significant.
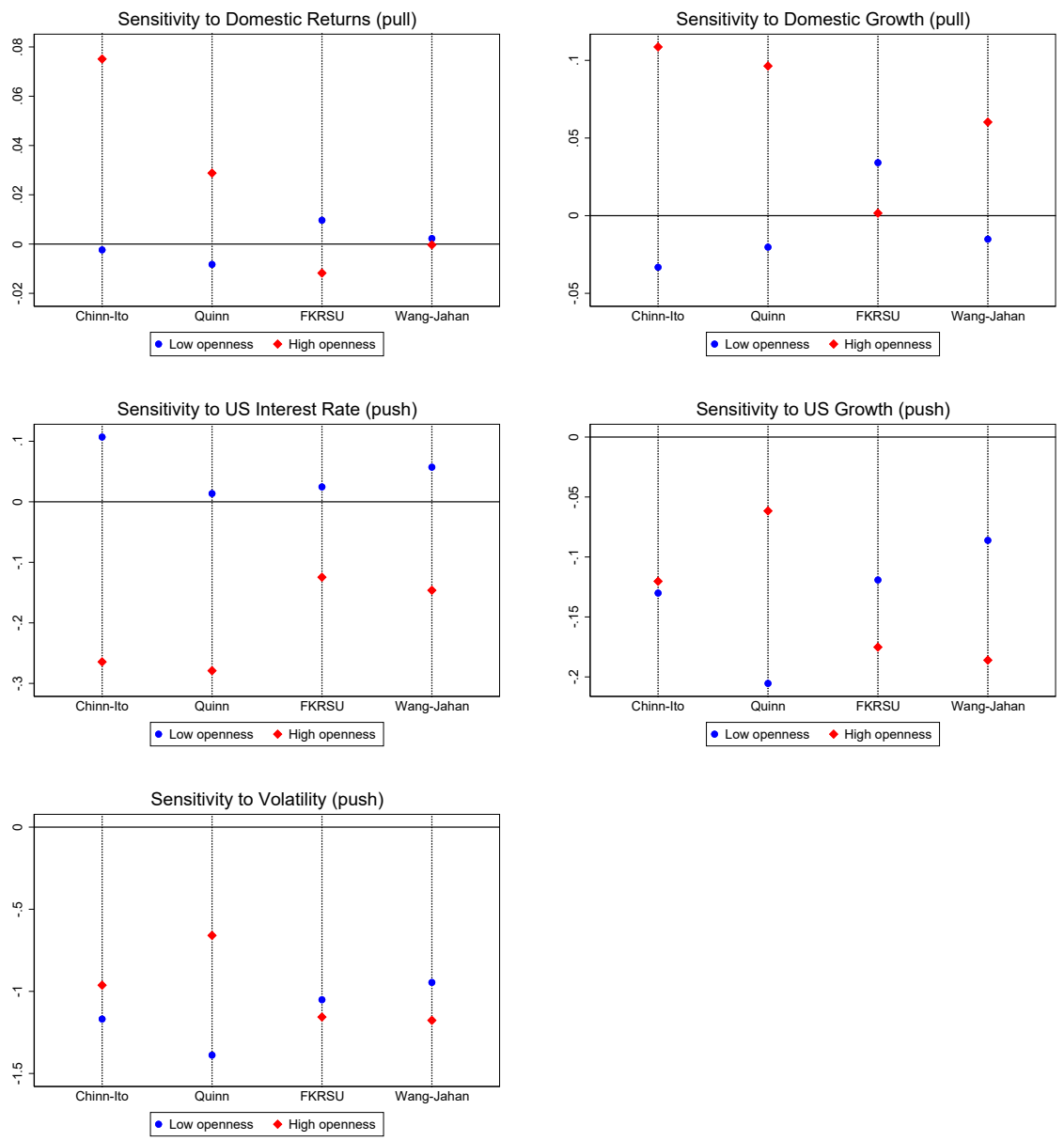

Figure 4: The effect of pull and push factors on portfolio equity inflows as a function of financial openness. The panels show the estimated effects reported in Table 1 of Appendix A.2 for countries at the 25th (blue dot) and 75th (red diamond) percentiles of the financialopenness distribution.

Figure 5 presents the results for portfolio debt inflows. We find, across all financial 
openness measures, that for a country on the 25th percentile of the openness distribution portfolio debt inflows do not respond to changes in expected domestic returns. On the contrary, there is some evidence that more open countries see a differential effect, with point estimates ranging from 0.05 to 0.25 percent of GDP when expected domestic returns are one percentage point higher. The interaction term, however, is only significant under two of the openness measures. The differential effect of U.S. interest rates is consistent across all but one measure (with the more open country seeing a 0.1-percent-of-GDP larger inflow decline than the more closed country), but they are imprecisely estimated. The differential effects of expected U.S. growth and volatility are too mixed across measures to be able to say that more open countries are more exposed to these push factors. ${ }^{18}$

Lastly, the portfolio debt regressions deliver one counter-intuitive result, namely that the more closed (open) country sees an increase (decrease) in inflows when domestic growth is higher, with the interaction term being statistically significant under some financial openness measures. The result proved robust to using financial openness measures for specific asset classes and to outlier treatments. ${ }^{19}$ One possible explanation for the result relates to the fact that portfolio debt inflows include official debt flows. If sovereigns in more open countries tend to issue more pro-cyclically - i.e. issuing less when growth is high (because tax revenues are high) - then the expected configuration of responses to higher domestic growth is as shown in Figure 5.

Figure 6 presents the differential effects of pull and push factors on FDI inflows, as measured by point estimates. Likely because FDI decisions are based on factors other than the higher-frequency phenomena captured by many of our pull and push factors, most of

\footnotetext{
${ }^{18}$ Work by Nier, Sedik and Mondino (2014) finds that countries with a higher degree of financial openness are more susceptible to changes in VIX. Our results show that this result is not robust to changing the way financial openness is measured.

${ }^{19}$ We carefully assessed the robustness of this set of results in a number of ways. Results are virtually unchanged when replacing the overall Wang-Jahan and FKRSU inflow restrictiveness indices with portfolio debt inflows-specific indices. We also explored the possibility that the results are driven by overly-influential observations, correcting for outliers based on Cook's distance and via robust regression. In the case of Cook's distance, after a preliminary estimation of equation (3), we dropped all observations with a Cook distance greater than $4 / N$, where $N$ denotes the sample size (Cook, 1977). The robust regression approach is based on Yohai (1987). The results proved robust to these corrections.
} 

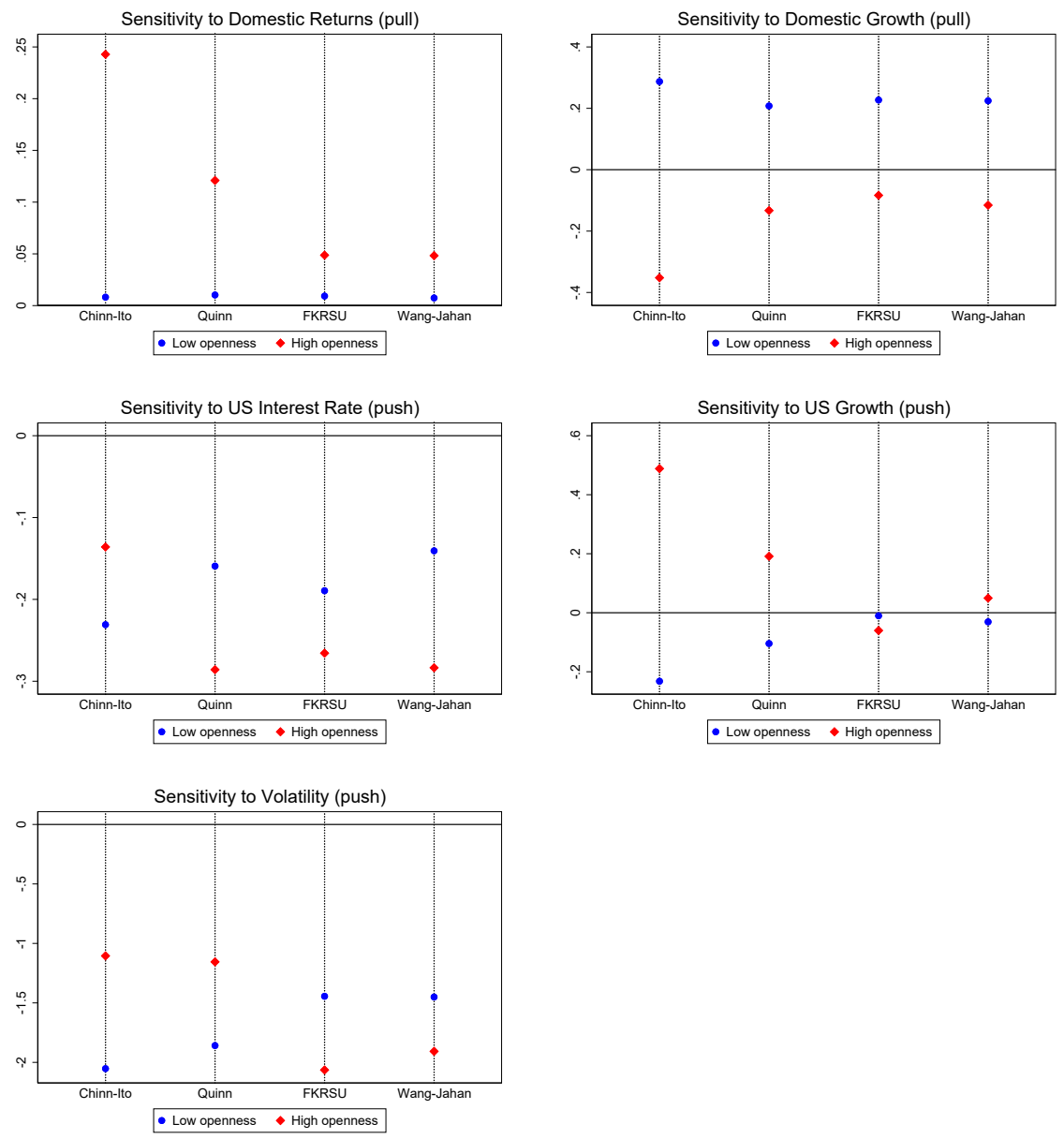

Figure 5: The effect of pull and push factors on portfolio debt inflows as a function of financial openness. The panels show the estimated effects reported in Table 2 of Appendix A.2 for countries at the 25th (blue dot) and 75th (red diamond) percentiles of the financialopenness distribution.

the interaction terms in these regressions are not statistically significant, and there is also substantial noise in terms of how different point estimates look across financial openness measures. The one exception to this is the role played by expected domestic growth. Depending on how financial openness is measured, a country on the 75th percentile of the openness distributions may receive almost one percentage points of GDP higher FDI inflows when expected domestic growth is one percentage point higher, compared to a country on the 25th percentile. 

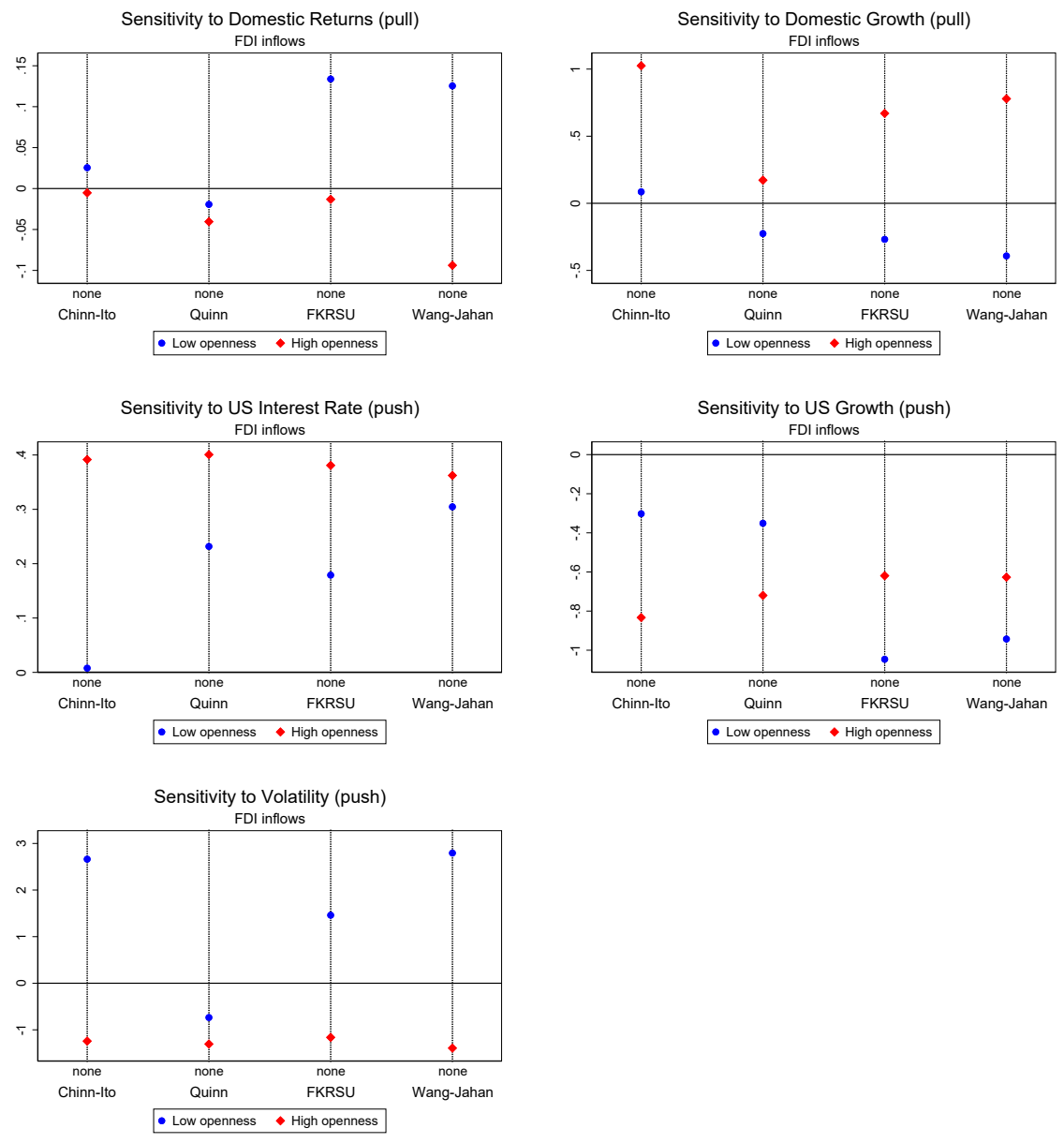

Figure 6: The effect of pull and push factors on FDI inflows as a function of financial openness. The panels show the estimated effects reported in Table 3 of Appendix A.2 for countries at the 25th (blue dot) and 75th (red diamond) percentiles of the financial-openness distribution.

\section{Conclusion}

Based on a simple small open economy model, we derived an empirical framework to think about the effect of capital controls on the volume of emerging market capital inflows. This theory-consistent framework resembles the workhorse push-pull regressions from the literature, but introduces interaction terms between the degree of financial openness and domestic pull and external push factors. The implication is that the sensitivity of capital inflows to traditional driving forces depends on the country's capital account restrictiveness.

Coincidentally, the inclusion of interaction terms also addresses some well-known empir- 
ical challenges in identifying the impact of capital account restrictions from cross-country data. Importantly, our approach can exploit the large dispersion of de jure financial openness across emerging economies, while most studies rely on the fairly limited time series variation in countries' capital account policies. Furthermore, the low consistency of standard financial openness indicators over time highlights serious measurement uncertainties in the literature, and casts doubts on the robustness of these results. Our regressions are more suitable to confront these measurement problems, because we show that the same indicators are highly consistent when comparing openness across the cross-section of countries. Based in this evidence, we argue that our carefully-derived framework should help extract from the data any cross-country information there might be on the relationship between financial openness and capital flows.

Our main finding is that there are very few such relationships that are statistically robust to measurement uncertainties. The cross-country data is rarely conclusive enough to confirm the theoretical predictions about the effects of capital controls. Still, a few results emerge that are stable across specifications and provide modest support for the efficacy of capital flow restrictions to steer capital flows. For example, in more financially open countries portfolio equity inflows are more exposed to the external interest rate environment, while debt inflows are much more responsive to the domestic business cycle than in more closed economies. The results are generally consistent with countries' ability to dampen the volatility of capital flow cycles using capital flow management measures. More broadly, the evidence suggests that countries with a higher degree of financial openness are more susceptible to some, but by no means all, push and pull factors. 
Figure 7: Correlation between IIF and official balance of payments inflows data.

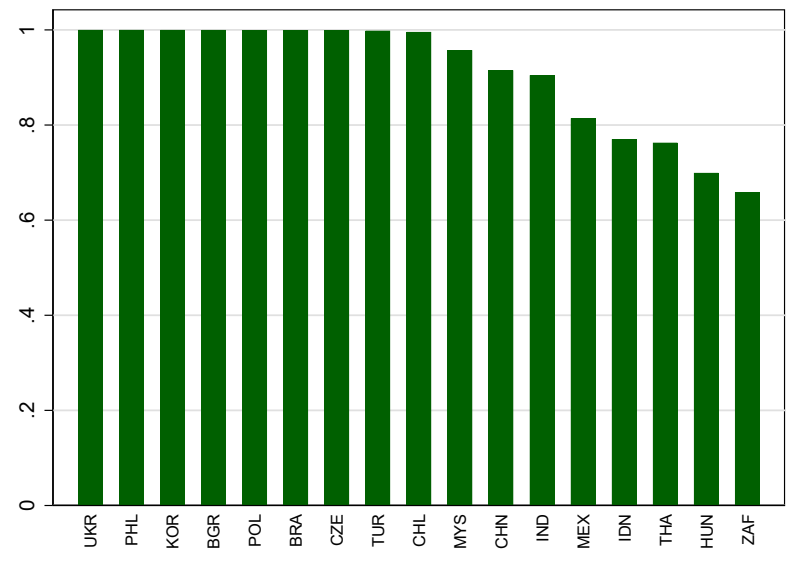

(a) Portfolio debt

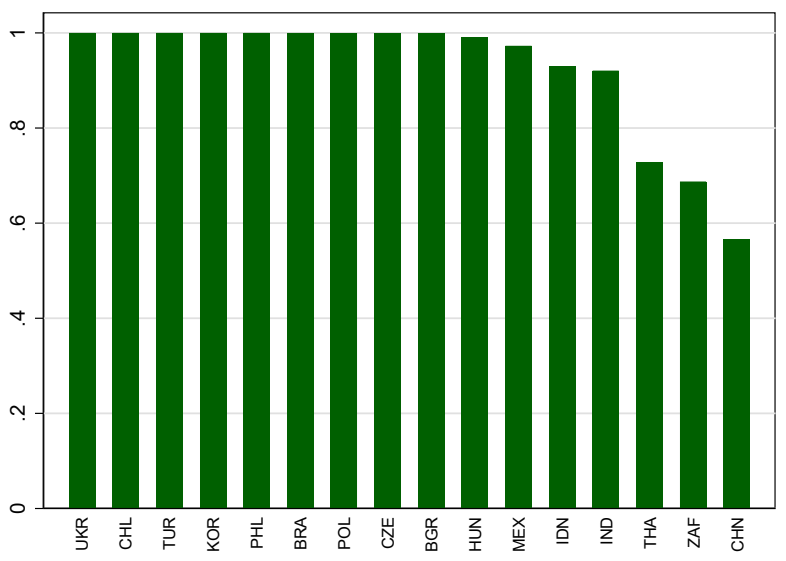

(b) Portfolio equity

\section{A Appendix}

\section{A.1 IIF and balance of payments data}

IIF monthly porfolio debt and portfolio equity capital flows data are constructed from official sources. Figure 7 shows the correlation between IIF data aggregated to a quarterly frequency and balance of payments data obtained from the World Economic Outlook database. In most cases, the IIF series matches the quarterly BOP data exactly. The fact that this does not hold for some countries is because of revisions done to the quarterly series that are not reflected in revised monthly series.

Figure 8 shows the correlation of official quarterly BOP data with another common source of monthly capital flows data, those compiled by Emerging Portfolio Fund Research (EPFR). EPFR data track portfolio equity and bond flows by some classes of investors. While it provides high-frequency data on the non-resident transactions that are of interest to us in our paper, its match with BOP data is relatively poor. Understanding what drives the correlation of EPFR and BOP data for a particular country is also not straightforward, given that in some cases EPFR appears to track well a certain type of inflow but is virtually orthogonal to other inflow types. For these reasons, our analysis is based solely on the data 
Figure 8: Correlation between EPFR and official balance of payments inflows data.

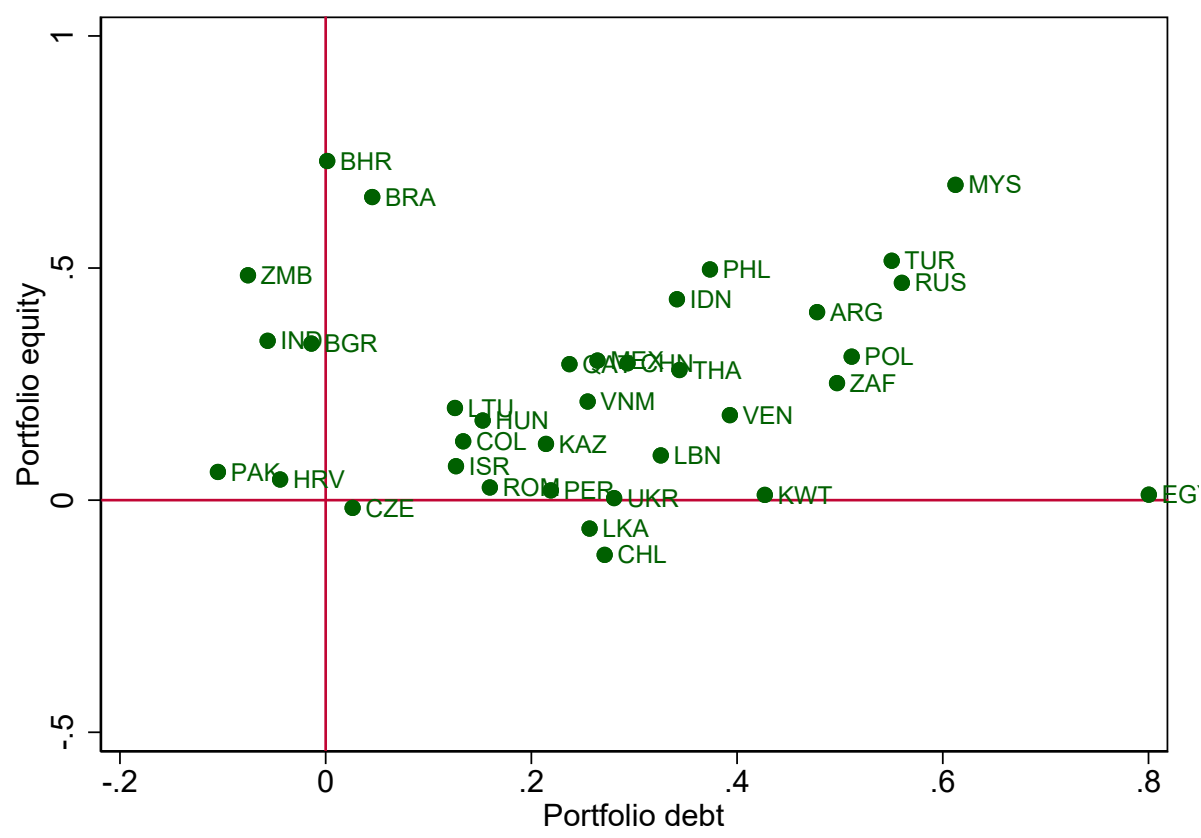

produced by IIF.

\section{A.2 Panel data estimates}


Table 1: Capital flow component: Portfolio equity

\begin{tabular}{|c|c|c|c|c|}
\hline & $\begin{array}{c}(1) \\
\text { Chinn-Ito }\end{array}$ & $\begin{array}{c}(2) \\
\text { Quinn }\end{array}$ & $\begin{array}{c}(3) \\
\text { FKRSU }\end{array}$ & $\begin{array}{c}(4) \\
\text { Wang-Jahan }\end{array}$ \\
\hline US growth & $\begin{array}{l}-0.13^{*} \\
(0.08)\end{array}$ & $\begin{array}{c}-0.35^{* *} \\
(0.20)\end{array}$ & $\begin{array}{l}-0.07 \\
(0.13)\end{array}$ & $\begin{array}{l}-0.04 \\
(0.16)\end{array}$ \\
\hline US rate & $\begin{array}{c}0.18 \\
(0.20)\end{array}$ & $\begin{array}{l}0.31^{* *} \\
(0.16)\end{array}$ & $\begin{array}{l}0.14^{*} \\
(0.10)\end{array}$ & $\begin{array}{c}0.15 \\
(0.12)\end{array}$ \\
\hline Volatility & $\begin{array}{c}-1.21^{* * *} \\
(0.22)\end{array}$ & $\begin{array}{c}-2.12^{* * *} \\
(0.73)\end{array}$ & $\begin{array}{c}-0.97^{* *} \\
(0.47)\end{array}$ & $\begin{array}{l}-0.84^{*} \\
(0.50)\end{array}$ \\
\hline Dom. growth & $\begin{array}{l}-0.06 \\
(0.06)\end{array}$ & $\begin{array}{l}-0.14 \\
(0.16)\end{array}$ & $\begin{array}{c}0.06 \\
(0.13)\end{array}$ & $\begin{array}{l}-0.05 \\
(0.06)\end{array}$ \\
\hline Domestic return & $\begin{array}{l}-0.02 \\
(0.01)\end{array}$ & $\begin{array}{l}-0.05^{*} \\
(0.03)\end{array}$ & $\begin{array}{c}0.03 \\
(0.03)\end{array}$ & $\begin{array}{c}0.00 \\
(0.02)\end{array}$ \\
\hline Institutions & $\begin{array}{c}8.36^{* * *} \\
(3.52)\end{array}$ & $\begin{array}{l}8.17^{* * *} \\
(2.91)\end{array}$ & $\begin{array}{c}9.41^{* * *} \\
(3.58)\end{array}$ & $\begin{array}{c}8.69^{* * *} \\
(3.91)\end{array}$ \\
\hline Openness & $\begin{array}{l}-0.70 \\
(1.55)\end{array}$ & $\begin{array}{l}-7.31^{*} \\
(4.20)\end{array}$ & $\begin{array}{c}1.87 \\
(3.23)\end{array}$ & $\begin{array}{c}1.79 \\
(3.24)\end{array}$ \\
\hline x US growth & $\begin{array}{c}0.01 \\
(0.14)\end{array}$ & $\begin{array}{c}0.29 \\
(0.31)\end{array}$ & $\begin{array}{l}-0.11 \\
(0.22)\end{array}$ & $\begin{array}{l}-0.16 \\
(0.27)\end{array}$ \\
\hline $\mathrm{x}$ US rate & $\begin{array}{l}-0.45^{*} \\
(0.29)\end{array}$ & $\begin{array}{c}-0.59^{* * *} \\
(0.23)\end{array}$ & $\begin{array}{l}-0.30^{*} \\
(0.22)\end{array}$ & $\begin{array}{l}-0.32^{*} \\
(0.18)\end{array}$ \\
\hline x Volatility & $\begin{array}{c}0.25 \\
(0.46)\end{array}$ & $\begin{array}{l}1.46^{*} \\
(0.95)\end{array}$ & $\begin{array}{l}-0.21 \\
(0.94)\end{array}$ & $\begin{array}{l}-0.36 \\
(1.02)\end{array}$ \\
\hline x Dom. growth & $\begin{array}{c}0.17 \\
(0.13)\end{array}$ & $\begin{array}{c}0.23 \\
(0.25)\end{array}$ & $\begin{array}{l}-0.06 \\
(0.22)\end{array}$ & $\begin{array}{c}0.12 \\
(0.16)\end{array}$ \\
\hline x Domestic return & $\begin{array}{c}0.09^{* * *} \\
(0.03)\end{array}$ & $\begin{array}{l}0.07^{*} \\
(0.05)\end{array}$ & $\begin{array}{l}-0.04 \\
(0.06)\end{array}$ & $\begin{array}{l}-0.00 \\
(0.06)\end{array}$ \\
\hline$R^{2}$ & 0.047 & 0.058 & 0.041 & 0.039 \\
\hline Observations & 2065 & 2065 & 2065 & 2041 \\
\hline Countries & 16 & 16 & 16 & 16 \\
\hline
\end{tabular}

Notes: ${ }^{*} 20$ percent significance, ${ }^{* *} 10$ percent, ${ }^{* * *} 5$ percent. 
Table 2: Capital flow component: Portfolio debt

\begin{tabular}{|c|c|c|c|c|}
\hline & $\begin{array}{c}(1) \\
\text { Chinn-Ito }\end{array}$ & $\begin{array}{c}(2) \\
\text { Quinn }\end{array}$ & $\begin{array}{c}(3) \\
\text { FKRSU }\end{array}$ & $\begin{array}{c}(4) \\
\text { Wang-Jahan }\end{array}$ \\
\hline US growth & $\begin{array}{c}-0.38^{* *} \\
(0.20)\end{array}$ & $\begin{array}{l}-0.40 \\
(0.43)\end{array}$ & $\begin{array}{c}0.03 \\
(0.28)\end{array}$ & $\begin{array}{l}-0.07 \\
(0.22)\end{array}$ \\
\hline US rate & $\begin{array}{l}-0.25^{*} \\
(0.15)\end{array}$ & $\begin{array}{l}-0.03 \\
(0.40)\end{array}$ & $\begin{array}{l}-0.13 \\
(0.16)\end{array}$ & $\begin{array}{l}-0.08 \\
(0.15)\end{array}$ \\
\hline Volatility & $\begin{array}{c}-2.24^{* * *} \\
(0.71)\end{array}$ & $\begin{array}{c}-2.56^{* *} \\
(1.39)\end{array}$ & $\begin{array}{l}-0.95 \\
(0.71)\end{array}$ & $\begin{array}{l}-1.25^{*} \\
(0.82)\end{array}$ \\
\hline Dom. growth & $\begin{array}{c}0.41^{* * *} \\
(0.12)\end{array}$ & $\begin{array}{c}0.55 \\
(0.45)\end{array}$ & $\begin{array}{l}0.48^{*} \\
(0.32)\end{array}$ & $\begin{array}{l}0.38^{* *} \\
(0.20)\end{array}$ \\
\hline Domestic return & $\begin{array}{l}-0.04 \\
(0.03)\end{array}$ & $\begin{array}{l}-0.10^{*} \\
(0.07)\end{array}$ & $\begin{array}{l}-0.02 \\
(0.09)\end{array}$ & $\begin{array}{l}-0.01 \\
(0.09)\end{array}$ \\
\hline Institutions & $\begin{array}{c}8.22 \\
(7.18)\end{array}$ & $\begin{array}{c}5.58 \\
(8.11)\end{array}$ & $\begin{array}{c}6.56 \\
(7.62)\end{array}$ & $\begin{array}{c}6.06 \\
(7.50)\end{array}$ \\
\hline Openness & $\begin{array}{l}-3.00 \\
(6.07)\end{array}$ & $\begin{array}{l}-3.22 \\
(8.62)\end{array}$ & $\begin{array}{c}6.34 \\
(6.40)\end{array}$ & $\begin{array}{c}5.20 \\
(6.30)\end{array}$ \\
\hline x US growth & $\begin{array}{l}0.86^{* *} \\
(0.49)\end{array}$ & $\begin{array}{c}0.59 \\
(0.70)\end{array}$ & $\begin{array}{l}-0.10 \\
(0.58)\end{array}$ & $\begin{array}{c}0.13 \\
(0.47)\end{array}$ \\
\hline $\mathrm{x}$ US rate & $\begin{array}{c}0.11 \\
(0.33)\end{array}$ & $\begin{array}{l}-0.25 \\
(0.62)\end{array}$ & $\begin{array}{l}-0.15 \\
(0.42)\end{array}$ & $\begin{array}{l}-0.22 \\
(0.40)\end{array}$ \\
\hline x Volatility & $\begin{array}{c}1.14 \\
(1.52)\end{array}$ & $\begin{array}{c}1.41 \\
(2.19)\end{array}$ & $\begin{array}{l}-1.24 \\
(1.68)\end{array}$ & $\begin{array}{l}-0.71 \\
(1.74)\end{array}$ \\
\hline x Dom. growth & $\begin{array}{c}-0.77^{* * *} \\
(0.23)\end{array}$ & $\begin{array}{l}-0.68 \\
(0.65)\end{array}$ & $\begin{array}{l}-0.62 \\
(0.48)\end{array}$ & $\begin{array}{l}-0.53^{*} \\
(0.33)\end{array}$ \\
\hline x Domestic return & $\begin{array}{c}0.28^{* * *} \\
(0.08)\end{array}$ & $\begin{array}{l}0.22^{*} \\
(0.13)\end{array}$ & $\begin{array}{c}0.08 \\
(0.16)\end{array}$ & $\begin{array}{c}0.06 \\
(0.18)\end{array}$ \\
\hline$R^{2}$ & 0.025 & 0.021 & 0.018 & 0.020 \\
\hline Observations & 2251 & 2251 & 2251 & 2228 \\
\hline Countries & 17 & 17 & 17 & 17 \\
\hline
\end{tabular}

Notes: ${ }^{*} 20$ percent significance, ${ }^{* *} 10$ percent, ${ }^{* * *} 5$ percent. 
Table 3: Capital flow component: FDI inflows

\begin{tabular}{|c|c|c|c|c|}
\hline & $\begin{array}{c}(1) \\
\text { Chinn-Ito }\end{array}$ & $\begin{array}{c}(2) \\
\text { Quinn }\end{array}$ & $\begin{array}{c}(3) \\
\text { Wang-Jahan }\end{array}$ & $\begin{array}{c}(4) \\
\text { FKRSU }\end{array}$ \\
\hline US growth & $\begin{array}{l}-0.20 \\
(1.10)\end{array}$ & $\begin{array}{c}0.02 \\
(0.93)\end{array}$ & $\begin{array}{l}-1.08 \\
(1.16)\end{array}$ & $\begin{array}{l}-1.39 \\
(1.23)\end{array}$ \\
\hline US rate & $\begin{array}{l}-0.07 \\
(0.29)\end{array}$ & $\begin{array}{c}0.06 \\
(0.58)\end{array}$ & $\begin{array}{c}0.28 \\
(0.26)\end{array}$ & $\begin{array}{c}0.02 \\
(0.20)\end{array}$ \\
\hline Volatility & $\begin{array}{c}3.44 \\
(3.46)\end{array}$ & $\begin{array}{l}-0.17 \\
(1.40)\end{array}$ & $\begin{array}{c}4.65 \\
(4.06)\end{array}$ & $\begin{array}{c}3.56 \\
(4.19)\end{array}$ \\
\hline Dom. growth & $\begin{array}{l}-0.10 \\
(0.37)\end{array}$ & $\begin{array}{l}-0.62^{*} \\
(0.46)\end{array}$ & $\begin{array}{l}-0.91 \\
(0.93)\end{array}$ & $\begin{array}{l}-1.02 \\
(1.00)\end{array}$ \\
\hline Domestic return & $\begin{array}{c}0.03 \\
(0.05)\end{array}$ & $\begin{array}{c}0.00 \\
(0.04)\end{array}$ & $\begin{array}{c}0.22 \\
(0.19)\end{array}$ & $\begin{array}{c}0.25 \\
(0.22)\end{array}$ \\
\hline Institutions & $\begin{array}{l}13.54^{*} \\
(8.86)\end{array}$ & $\begin{array}{c}13.52^{* *} \\
(7.86)\end{array}$ & $\begin{array}{l}12.64 \\
(9.79)\end{array}$ & $\begin{array}{l}14.59^{*} \\
(11.07)\end{array}$ \\
\hline Openness & $\begin{array}{c}2.61 \\
(4.51)\end{array}$ & $\begin{array}{l}-2.35 \\
(4.86)\end{array}$ & $\begin{array}{l}-3.45 \\
(5.02)\end{array}$ & $\begin{array}{l}-9.54^{*} \\
(7.06)\end{array}$ \\
\hline x US growth & $\begin{array}{l}-0.64 \\
(1.25)\end{array}$ & $\begin{array}{l}-0.74 \\
(1.08)\end{array}$ & $\begin{array}{c}0.49 \\
(1.52)\end{array}$ & $\begin{array}{c}0.85 \\
(1.55)\end{array}$ \\
\hline $\mathrm{x}$ US rate & $\begin{array}{c}0.46 \\
(0.67)\end{array}$ & $\begin{array}{c}0.34 \\
(0.79)\end{array}$ & $\begin{array}{c}0.09 \\
(0.48)\end{array}$ & $\begin{array}{c}0.40 \\
(0.44)\end{array}$ \\
\hline x Volatility & $\begin{array}{l}-4.68 \\
(4.27)\end{array}$ & $\begin{array}{l}-1.14 \\
(2.36)\end{array}$ & $\begin{array}{l}-6.51 \\
(5.07)\end{array}$ & $\begin{array}{l}-5.24 \\
(5.08)\end{array}$ \\
\hline x Dom. growth & $\begin{array}{l}1.13^{* *} \\
(0.63)\end{array}$ & $\begin{array}{l}0.80^{*} \\
(0.48)\end{array}$ & $\begin{array}{l}1.82^{*} \\
(1.16)\end{array}$ & $\begin{array}{l}1.88^{*} \\
(1.16)\end{array}$ \\
\hline x Domestic return & $\begin{array}{l}-0.04 \\
(0.06)\end{array}$ & $\begin{array}{l}-0.04 \\
(0.07)\end{array}$ & $\begin{array}{l}-0.34^{*} \\
(0.24)\end{array}$ & $\begin{array}{l}-0.29 \\
(0.26)\end{array}$ \\
\hline$R^{2}$ & 0.007 & 0.013 & 0.011 & 0.011 \\
\hline Observations & 2341 & 2187 & 2163 & 2180 \\
\hline Countries & 42 & 40 & 42 & 38 \\
\hline
\end{tabular}

Notes: ${ }^{*} 20$ percent significance, ${ }^{* *} 10$ percent, ${ }^{* * *} 5$ percent. 


\section{References}

Arellano, Cristina, and Ananth Ramanarayanan. 2012. "Default and the Maturity Structure in Sovereign Bonds." Journal of Political Economy, 120(2): 187-232.

Bianchi, Javier, Juan Carlos Hatchondo, and Leonardo Martinez. 2018. "International Reserves and Rollover Risk." American Economic Review, 108(9): 2629-70.

Calvo, Guillermo A., Leonardo Leiderman, and Carmen M. Reinhart. 1993. "Capital Inflows and Real Exchange Rate Appreciation in Latin America: The Role of External Factors." Staff Papers (International Monetary Fund), 40(1): 108-151.

Chinn, Menzie D., and Hiro Ito. 2008. "A New Measure of Financial Openness." Journal of Comparative Policy Analysis: Research and Practice, 10(3): 309-322.

Cook, R. Dennis. 1977. "Detection of Influential Observation in Linear Regression." Technometrics, 19(1): 15-18.

Eichengreen, Barry, and Andrew Rose. 2014. "Capital Controls in the 21st Century." Journal of International Money and Finance, 48: 1 - 16.

Fernández, Andrés, Michael W Klein, Alessandro Rebucci, Martin Schindler, and Martín Uribe. 2016. "Capital Control Measures: A New Dataset." IMF Economic Review, 64(3): 548-574.

Fernandez-Arias, Eduardo. 1996. "The new wave of private capital inflows: Push or pull?" Journal of Development Economics), 48(2): 389-418.

Forbes, Kristin. 2005. "The Microeconomic Evidence on Capital Controls: No Free Lunch." NBER Working Paper 11372.

Ghosh, Atish R., Mahvash S Qureshi, and Naotaka Sugawara. 2014. "Regulating Capital Flows at Both Ends : Does it Work?" IMF Working Paper 14/188. 
Giordani, Paolo E., Michele Ruta, Hans Weisfeld, and Ling Zhu. 2017. "Capital flow deflection." Journal of International Economics, 105: 102 - 118.

Gosh, Atish R., Jonathan D. Ostry, and Mahvash S. Qureshi. 2018. Taming the Tide of Capital Flows : A Policy Guide. MIT Press.

Horn, Sebastian, and Futoshi Narita. forthcoming. "Opening Up: Capital Flows and Financial Sector Dynamics in Low-Income Developing Countries." IMF Working Paper.

IMF. 2016. "Capital Flows - Review of Experience with the Institutional View." International Monetary Fund.

Jahan, Sarwat, and Daili Wang. 2016. "Capital Account Openness in Low-income Developing Countries: Evidence from a New Database." IMF Working Paper 16/252, 1-26.

Jeanne, Olivier, and Anton Korinek. 2010. "Excessive Volatility in Capital Flows: A Pigouvian Taxation Approach." American Economic Review, 100(2): 403-07.

Koepke, Robin. 2015. "What Drives Capital Flows to Emerging Markets? A Survey of the Empirical Literature." University Library of Munich, Germany MPRA Paper 62770.

Korinek, Anton. 2018. "Regulating capital flows to emerging markets: An externality view." Journal of International Economics, 111: 61 - 80.

Lane, Philip R., and Gian Maria Milesi-Ferretti. 1999. "The External Wealth of Nations: Measures of Foreign Assets and Liabilities for Industrial and Developing Countries." IMF Working Paper 99/115, 1-57.

Lane, Philip R., and Gian Maria Milesi-Ferretti. 2007. "The external wealth of nations mark II: Revised and extended estimates of foreign assets and liabilities, 19702004." Journal of International Economics, 73(2): 223 - 250. 
Magud, Nicolas E., Carmen M. Reinhart, and Kenneth S. Rogoff. 2018. "Capital Controls: Myth and Reality-A Portfolio Balance Approach." Annals of Economics and Finance, 19(1): 1-47.

Nier, Erlend, Tahsin Saadi Sedik, and Tomas Mondino. 2014. "Gross Private Capital Flows to Emerging Markets: Can the Global Financial Cycle be Tamed?" IMF Working Paper), , (14/196).

Quinn, Dennis. 1992. "Measuring International Financial Openness." paper presented at the 1992 Annual Meetings of the American Political Science Association.

Quinn, Dennis, and A. Maria Toyoda. 2008. "Does Capital Account Liberalization Lead to Growth." Review of Financial Studies, 21: 1403-49.

Quinn, Dennis, Martin Schindler, and A. Maria Toyoda. 2011. "Assessing Measures of Financial Openness and Integration." IMF Economic Review, 59(3): 488-522.

Rey, Hélène. 2015. "Dilemma not Trilemma: The Global Financial Cycle and Monetary Policy Independence." NBER Working Paper 21162.

Schindler, Martin. 2009. "Measuring Financial Integration: A New Data Set." IMF Staff Papers, 56(1): 222-238.

Wu, Jing Cynthia, and Fan Dora Xia. 2016. "Measuring the Macroeconomic Impact of Monetary Policy at the Zero Lower Bound." Journal of Money, Credit and Banking, 48(2-3): 253-291.

Yohai, Victor J. 1987. "High Breakdown-Point and High Efficiency Robust Estimates for Regression." The Annals of Statistics, 15: 642-656. 